\title{
PENINGKATAN KOMPETENSI MEMBUAT GARNISH PADA MATA PELAJARAN BOGA DASAR MELALUI PEMANFAATAN MEDIA SOSIAL
}

\author{
Dian Setyowati \\ SMKN 2 Magetan \\ dian_jim@yahoo.com \\ Siti Hamidah \\ Program Pascasarjana Universitas Negeri Yogyakarta \\ hamidah_siti66@yahoo.com
}

\begin{abstract}
Abstrak
Penelitian ini bertujuan untuk mengetahui: (1) upaya meningkatkan kompetensi membuat garnish, (2) peningkatan kompetensi sikap, pengetahuan, dan keterampilan. Jenis penelitian ini adalah Penelitian Tindakan Kelas dengan dua siklus tindakan. Teknik pengumpulan data menggunakan observasi, tes tulis, tes kinerja dan analisa data secara deskriptif. Hasil penelitian yang didapatkan (1) untuk meningkatkan pembelajaran menggunakan media sosial yang terdiri dari Facebook, google, dan Youtube; (2) Ketercapaian secara umum pada siklus I dengan kategori baik dan siklus II dengan kategori sangat baik. Ketercapaian tersebut terdiri dari: (a) ranah sikap pada pembelajaran di luar kelas rata-rata mencapai kategori sangat baik, sedangkan ranah sikap siswa pada pembelajaran di dalam kelas rata-rata mencapai kategori sangat baik; (b) ranah pengetahuan mencapai kategori sangat baik; (c) ranah keterampilan mencapai sangat baik.
\end{abstract}

Kata kunci: kompetensi membuat garnis, mata pelajaran boga dasar, media sosial

\section{IMPROVING COMPETENCIES OF MAKING GARNISHES ON BASIC CULLINARY THROUGH SOCIAL MEDIA USAGE}

\begin{abstract}
This study aim to know: (1) the effort of improving students' competencies in making garnishes of food and beverages, (2) the improvement students' competencies that were consist of: affective, cognitive, and psicomotoric. This study was a classroom action research that was conducted on two cyclesThe data collection techniques included observations, written tests, and performance test. The data were analyzed descriptively. The result of the study indicates that (1) to improve the learning used the social media that consist of Facebook, google, dan Youtube; (2) generality, the attainment of students' competencies in cycle I on good category and in cycle II on very good category. The attainments were as follow: (a) the attainment of affective aspect in outside classroom average on very good category; The attainment of affective aspect in the average on very good category; (b) the attainment of cognitive aspect on very good category; (c) the attainment of psychomotoric aspect was on very good category.
\end{abstract}

Keywords: the competencies of making garnishes for food and beverages, basic cullinary, social media 


\section{PENDAHULUAN}

Garnish merupakan salah satu kompetensi dasar pada mata pelajaran Boga Dasar yang mengedepankan seni dengan membuat hiasan dari bahan makanan berupa buah atau sayur yang bertujuan untuk memperindah penampilan makanan dan juga bisa dimakan. Guggenmos \& McVety (2010, p.509) menyatakan bahwa "The word garnish comes from the French word garnir, meaning to decorate or furnish. In the culinary world, it means to use food as an attractive decoration." Istilah garnish berasal dari bahasa Prancis yaitu kata "garnir", yang artinya menghias atau melengkapi. Dalam dunia kuliner, garnish menjadikan makanan sebagai sebuah hiasan yang menarik.

Kompetensi garnish merupakan kompetensi di bidang boga yang mengutamakan keahlian dalam mengukir atau membentuk bahan makanan menjadi suatu barang yang artistik yang selalu berkembang. Hal ini dapat dibuktikan bahwa pada berbagai media massa dan di seluruh negara di dunia selalu tercipta jenis seni garnish baru.

Selanjutnya dijelaskan oleh Nunung (2002, p.2) bahwa garnish merupakan hiasan pada makanan yang berfungsi menambah cantik penampilan hidangan sehingga menambah selera makan. Hiasan makanan yang dipergunakan berasal dari bahan makanan seperti buah dan sayur yang dibentuk atau diukir. Berdasarkan penyatan-pernyataan tersebut garnish merupakan hiasan pada makanan yang berfungsi menjadikan makanan tersebut tampil lebih menarik dan menggugah selera makan.

Fungsi garnish pada makanan antara lain: (a) menambah nilai estetika suatu hidangan, (b) menggugah selera makan, (c) memberi nilai tambah pada penjualan hidangan tersebut. Dengan demikian garnih merupakan center piece suatu hidangan yang ikut menentukan nilai jual hidangan tersebut. Semakin cantik penampilan suatu hidangan maka semakin tinggi nilai jual hidangan tersebut.

Hal ini sesuai dengan yang diutarakan oleh Guggenmos \& McVety (2010, p.508) bahwa penampilan makanan merupakan pandangan atau indikator pertama yang menyatakan bagaimanakah rasa dan kelezatan makanan tersebut. Semakin menyala dan penuh warna makanan itu maka semakin indah dilihat. Para pelanggan lebih menyukai hidangan yang penuh warna dan menarik.

Pada kenyataannya, rasa yang ditimbulkan pada pandangan sangat memegang peranan penting yang menyebabkan pesan-pesan lain yang diterima oleh sensor lainnya tidak diterima. Dengan demikian warna dan penampilan makanan dituntut menarik perhatian pelanggan meskipun dengan bagaimanapun rasa makanan tersebut. Penampilan mampu mewakili kelezatan sebuah hidangan yang dapat menggambarkan bagaimana rasa, aroma, dan tekstur hidangan tersebut. Hal ini terjadi karena pada umumnya masyarakat sangat mengutamakan pada penampilan atau tampilan makanan.

Penampilan yang ditunjukkan sebuah hidangan ditunjang oleh adanya garnish. Arti penting garnish yang mewakili hidangan yang ditampilkan memberikan aturan yang jelas agar hidangan tersebut dapat diterima konsumen. Adapun karakteristik atau syarat-syarat bahan garnish yang harus dipenuhi, antara lain: garnish tersebut dapat dimakan, bahan garnish tidak berbau tajam, tidak mengandung zat beracun atau berbahaya, bahan garnish tidak terlalu lunak (matang) agar dapat dibentuk dengan mudah, bahan tidak mudah luntur. Kriteria garnish yang bagus dapat dilihat diantaranya dari kerapian bentuk garnish, kebersihan, tebal tipisnya potongan atau sayatan untuk kemudahan pembentukan, kekokohan bentuk, dan juga perpaduan warna.

Keberadaan garnish pada makanan sangat penting dimana dengan penambahan garnish maka makanan memiliki daya jual yang lebih tinggi. Bahkan di hotel-hotel berbintang maupun di restoran-restoran berkelas, seni kuliner dengan penampilan hidangan yang disertai garnish merupakan syarat mutlak untuk disajikan kepada tamu. Dengan demikian garnish merupakan sebuah keahlian yang saat ini menjadi sangat penting dalam dunia kuliner yang akan turut serta mendongkrak dunia pariwisata.

Berdasarkan arti penting dan komplektifitas kompetensi garnish tersebut maka perlu adanya inovasi dalam hal penyampaian materi kepada siswa agar materi yang selalu up to date dapat tersampaikan dan siswa kompeten baik pada basic pengetahuan garnish maupun kemampuan lanjutan. 
Pembelajaran membuat garnish makanan dan minuman di SMK Negeri 2 Magetan selama ini menggunakan teknik demonstrasi di depan kelas dan menggunakan gambar-gambar hasil garnish. Siswa mengamati Guru yang memberi tutorial di depan kelas dan bimbingan individu. Siswa yang dibimbing akan mengamati demonstrasi guru sedangkan siswa yang lain menunggu guru mendekati mereka. Hal ini berakibat siswa diluar jangkauan guru menjadi tidak dapat mengamati. Beberapa siswa berpindah tempat berusaha mencari tahu dengan menanyakan kepada temannya yang lain sehingga suasana kelas menjadi gaduh.

Pada beberapa kasus setelah siswa mengalami kesulitan mendapatkan informasi tentang teknik membuat garnish dengan benar, beberapa siswa mangalami keputusasaan dan malas untuk mempelajarinya kembali di luar pembelajaran. Permasalahan-permasalahan tersebut menyebabkan perbedaan pemahaman terhadap materi yang diterima antara satu siswa dengan siswa yang lain sehingga tujuan pembelajaran belum tercapai secara maksimal. Hal ini ditunjukkan dengan nilai rata-rata hasil praktik membuat garnish makanan dan minuman masih sedikit diatas Kriteria Ketuntasan Minimal (KKM), yaitu 75,52 dan ketuntasan belajar mencapai $68,18 \%$. Meskipun nilai sudah memenuhi KKM, namun pencapaian ketuntasan belajar belum tuntas sehingga perlu adanya peningkatan kemampuan siswa agar dapat mencapai kemampuan membuat garnish yang sesuai dengan tuntutan standar perusahaan.

Usaha yang pernah dilakukan untuk mengatasi masalah tersebut diantaranya siswa mengikuti demontrasi yang dilakukan berulang kali sampai semua siswa mencapai kompetensi yang sama. Setiap kelompok siswa yang didekati guru mendapatkan demonstrasi mulai dari teknik awal sampai akhir. Cara tersebut membutuhkan waktu yang lama sehingga menghabiskan waktu dan menunda pencapaian kompetensi berikutnya. Berdasarkan evaluasi hasil pembelajaran tersebut rata-rata siswa masih mengalami kesulitan menyamakan pemahaman terhadap apa yang didemonstrasikan oleh guru.

Hal ini menunjukkan bahwa teknik mengajar yang selama ini dilakukan belum efektif dan belum efisien. Demostrasi harus dilakukan berulang kali ketika berkeliling di dalam kelas, siswa belum bisa menyamakan pemahaman yang sama dalam sekali pembelajaran, siswa tidak dapat belajar secara mandiri di luar pertemuan di kelas untuk mengasah skill membuat garnish sedangkan pertemuan di kelas terbatas pada waktu pembelajaran yang singkat. Sedangkan pembelajaran praktik memerlukan waktu yang lebih luas untuk mencapai skill sesuai yang diharapkan. Hal ini sesuai pendapat Leighbody dan Kidd (1968, pp.5-6) bahwa Pembelajaran praktik membantu siswa untuk membentuk skill yang dilakukan secara berulang-ulang sehingga akan tertanam dalam diri siswa secara mendalam dan kemudian akan menjadi habit atau pembiasaan.. Kebiasaan yang tertanam dalam diri siswa akan tercermin dalam prilaku siswa sehari-hari. Demikian juga skill yang tertanam sebagai habit siswa akan tercermin dalam kebiasaan kerja siswa baik dalam pembelajaran praktik maupun dunia kerja sebenarnya.

Permasalahan lain yang dihadapai adalah keterbatasan lahan SMK Negeri 2 Magetan yang berdampak pada jumlah ruangan yang tidak seimbang dengan jumlah rombel sehingga ruang laboratorium juga digunakan untuk ruang teori. Sementara ruang lab sendiri belum memenuhi syarat standar sebagai ruang untuk melakakukan demonstrasi membuat garnish.

Sistem penggunaan ruang diberlakukan sistem moving class dimana penggunaan kelas diatur bergantian menyesuaikan pelajaran pada hari tersebut. Hal ini merupakan sebuah sistem perpindahan kelas yang mempengaruhi kondisi psikologis siswa. Pada satu sisi, siswa tidak mengalami kejenuhan pada satu ruangan saja yang ditempati. Tetapi siswa juga mengalami penurunan konsentrasi pada setiap pergantian pelajaran dan berkurangnya waktu karena digunakan untuk perpindahan dari kelas satu ke kelas berikutnya. Kondisi tersebut juga merupakan salah satu alasan diperlukannya sistem pembelajaran inovatif yang dapat dengan cepat menarik kembali konsentrasi siswa untuk mengikuti pelajaran di kelas.

Berdasarkan beberapa permasalahan tersebut perlu diupayakan pembelajaran yang kreatif dan menyenangkan. Kegiatan pembe- 


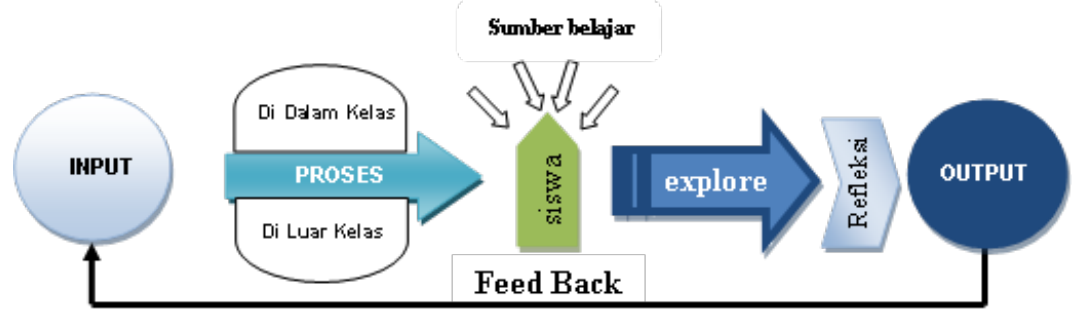

Gambar 1. Proses Pelaksanaan Pembelajaran Konstruktivis

lajaran yang kreatif dan menyenangkan dapat diciptakan oleh guru dengan keahliannya dalam mengelola kelas dengan metode-metode pembelajaran yang menyenangkan dan membuat siswa mudah memahami materi yang disampaikan, menggunakan sarana prasarana secara kreatif dan maksimal, mengoptimalkan kemampuan siswa dengan selalu menggali dan mengembangkan potensi diri siswa, memanfaatkan media-media pembelajaran serta memodifikasinya agar lebih menarik dan interaktif. Metode pembelajaran yang diperlukan dalam pembelajaran membuat garnish makanan dan minuman adalah metode pembelajaran konstruktivis.

Konstruktivis dalam bahasa inggris berasal dari kata construct yang berarti membangun. Konstruktivis mengandung arti membangun dan mengembangkan apa yang telah diketahui untuk mencapai tujuan. Model pembelajaran konstruktivis merupakan model pembelajaran "Student Centered Learning" yang menuntut siswa berperan secara aktif dengan mengexplore dan membangun pengetahuan serta keterampilan membuat garnish yang didapatkan agar pengetahuan dan keterampilan tersebut semakin berkembang.

Menurut Smaldino (2008, p.11) bahwa konstruktivis merupakan perubahan yang berpedoman terhadap keyakinan tentang pemahaman teori. Konstruktivis menganggap bahwa keikutsertaan siswa dalam memperoleh pengalaman belajar merupakan pengalaman belajar yang paling penting. Perubahan tersebut adalah dari pemindahan informasi yang bersifat pasif menjadi aktif memcahkan masalah dan menemukan. Konstuktivis menekankan bahwa pelajar membangun interpretasi atau tafsiran mereka sendiri tentang dunia informasi. Siswa dipacu untuk mencari informasi, menemukan dan membangun peemahaman mereka sendiri terhadap informasi tersebut dan mengembangkannya menjadi sebuah pemikiran atau karya inovatif. Dengan demikian pemahaman terhadap informasi atau ilmu yang didapatkan akan lebih mendalam dan tertanam kuat dalam ingatan siswa.

Berdasarkan pernyataan di atas maka dapat digambarkan bagan proses pelaksanaan pembelajaran konstruktivis dapat dilihat pada gambar 1.

Pada gambar 1 menjelaskan bahwa input utama dari metode pembelajaran Konstruktivis adalah adanya rancangan tugas yang bersifat open ended (terbuka, tidak terbatas) yang diperkuat dengan konsep teori pendukung. Proses pembelajaran terdiri dari proses di dalam kelas dan di luar kelas.

Pembelajaran di dalam kelas dilaksanakan dengan menggali pengetahuan dan keterampilan serta didukung dengan pembentukan sikap untuk mencapai kompetensi yang diharapkan. Pembelajaran di kelas diberikan tugas yang dikerjakan secara berkelompok maupun perorangan, kemudian setiap individu mengembangkan pengetahuan dan keterampilan yang didapatkan dengan mengkonstruk atau membangun dan menggali pengetahuan tersebut dalam kehidupan nyata. Proses mengembangkan pengetahuan dan keterampilan tersebut dapat dilakukan di luar pembelajaran di kelas dengan memanfaatkan berbagai sumber belajar.

Output utama dari model pembelajaran konstruktif adalah pengalaman dalam menggali dan mengembangkan pengetahuan dan keterampilan dalam kehidupan sehari-hari sehing- 
ga ilmu yang didapatkan lebih mendalam. Evaluasi input, proses, dan output ini merupakan feed back untuk perbaikan kegiatan pembelajaran selanjutnya.

Prinsip pembelajaran Konstruktivis adalah setelah siswa menerima ilmu, siswa mam$\mathrm{pu}$ mengembangkan dan menggali informasi mengenai materi terkait lebih dalam dari berbagai sumber pembelajaran, sehingga siswa tidak hanya menerima informasi dari guru. Selain itu siswa dituntut agar mampu menghubungkan ilmu yang didapatkan dengan kehidupan sehari-hari sebagai refleksi pembelajaran sehingga dapat dipergunakan sebagai acuan perbaikan pembelajaran berikutnya.

Guna menunjang keberhasilan metode yang diterapkan, maka diperlukan sebuah media pembelajaran yang tepat. Media pembelajaran yang sudah dikembangkan sampai saat ini sangat banyak jenisnya. Diantara beberapa media pembelajaran yang ada, pada hakikatnya tidak ada satupun metode pembelajaran yang benar dan salah, akan tetapi media pembelajaran yang tepat adalah media pembelajaran yang sesuai dengan materi dan karakteristik siswa pada kelas tersebut. Dan saat ini media sosial mulai dimanfaatkan dalam pembelajaran sebagai media untuk mempermudah siswa mendapatkan pengetahuan dan informasi serta memperlancar komunikasi antar siswa maupun antara siswa dengan guru di luar pembelajaran di kelas.

Media sosial (Social Network) atau media jejaring sosial atau global social web merupakan suatu jejaring sosial yang berada di internet yang mempunyai cakupan dari sistem software yang memungkinkan pengguna dapat berinteraksi dan berbagi data dengan pengguna yang lain dalam skala yang besar baik dalam negeri maupun luar negeri tanpa ada batasan wilayah (Nazar, 2010, p.1). Dengan demikian media sosial dapat diartikan sebagai sebuah media yang berbasis internet yang digunakan untuk berinteraksi, berpartisipasi, berdiskusi, berkolaborasi, berbagi, serta menciptakan dan berbagi isi secara online yang tidak dibatasi oleh ruang dan waktu.

Jenis-jenis media sosial yang saat ini disebut dengan global social web dapat digambarkan dalam diagram gambar 2. (sumber: www. fredcavazza.net):

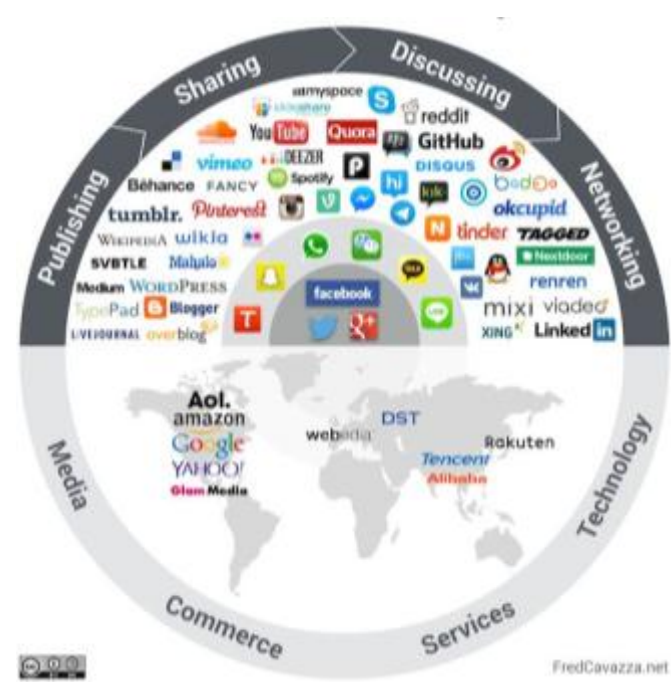

Gambar 2. Diagram Jenis-jenis Media Sosial/ Global Social Web (www.fredcavazza.net)

Gambar 2 menggambarkan bahwa terdapat 3 jenis media sosial utama yaitu facebook, twitter, dan google +. Ketiga media tersebut menyediakan sarana yang luas bagi user untuk mengumumkan, berbagi, berdiskusi, dan membuat jaringan. Dan media sosial yang paling dikebal oleh masyarakat adalah facebook.

Hal ini sesuai dengan pernyataan Mangkulo (2010, pp.5-6) bahwa facebook telah menempati peringkat kedua dari semua situs yang ada di seluruh dunia dan Amerika. Sedangkan di Indonesia, Facebook menempati urutan pertama, yang artinya jumlah pengguna facebook di Indonesia sudah sangat luas. Pernyataan tersebut menunjukkan bahwa masyarakat sangat akrab dengan media sosial, khususnya facebook. Fenomena ini ditunjang dengan dukungan teknologi yang semakin canggih dengan hadirnya smarthphone yang terkoneksi dengan internet. Hal ini juga didukung dengan adanya Vendor-vendor yang menawarkan paket internetan yang murah dan cepat.

Berdasarkan fakta-fakta tersebut, semakin menunjukkan bahwa saat ini para siswa sangat akrab dengan media sosial dan bahkan siswa sangat tertarik untuk selalu mengaksesnya. Hal ini merupakan kesempatan yang sangat baik bagi dunia pendidikan pada umumnya dan khususnya pada pembelajaran membuat garnish untuk memanfaatkan media sosial seperti facebook yang sedang menjadi pusat perhatian para siswa. Hal ini bertujuan agar pembelaja- 


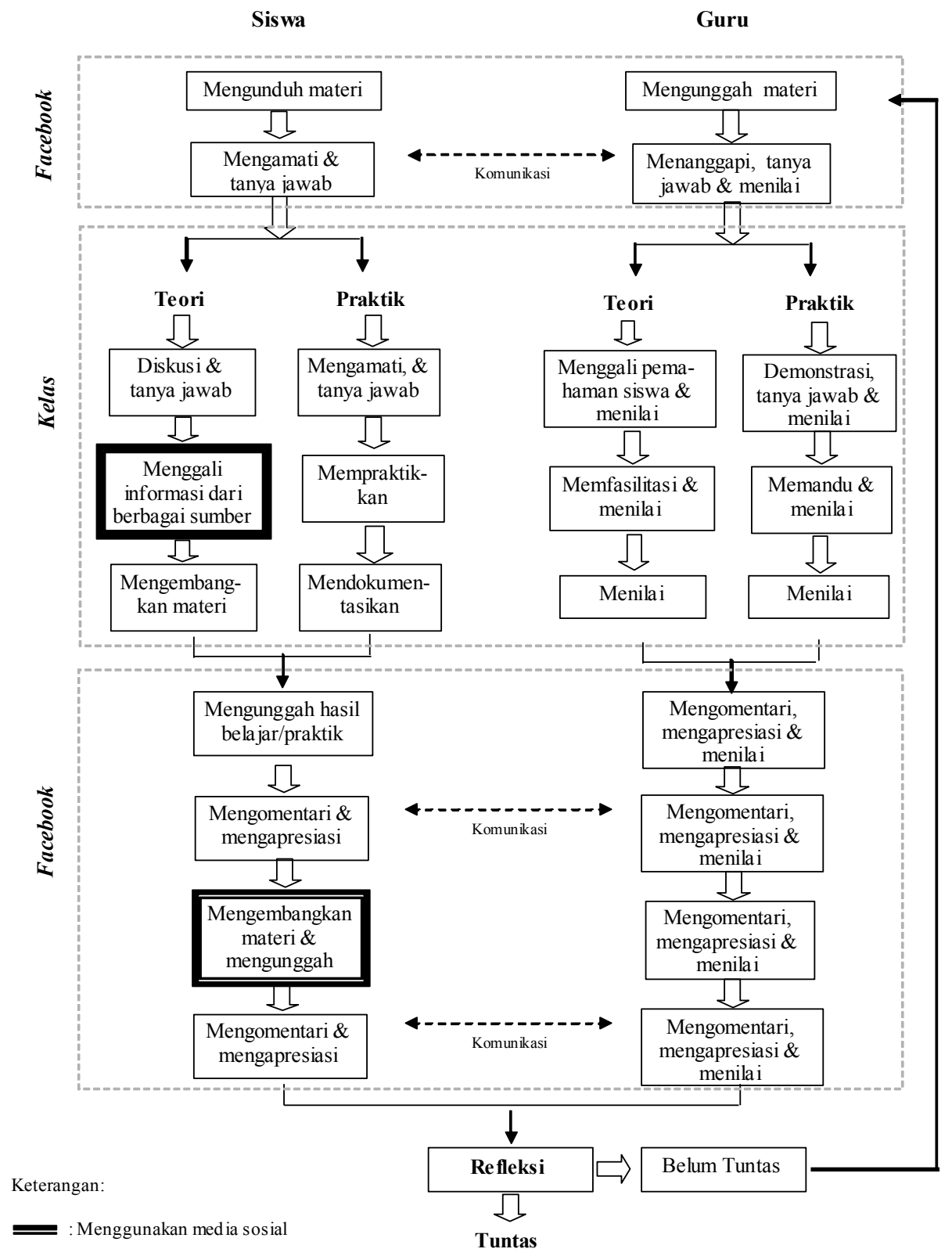

Gambar 3. Langkah Pembelajaran menggunakan Media Sosial

ran membuat garnish makanan dan minuman bisa juga diakses siswa di luar jam pembelajaran di kelas dan bisa terjalin komunikasi yang intensif dan positif antara guru dan murid melalui facebook.

Implikasi penggunaaan Facebook dalam pembelajaran adalah siswa dan guru dapat saling berkomunikasi dalam group facebook yang telah dibuat. Untuk mengatasi keterbatasan ruang kelas yang mengakibatkan siswa tidak bisa melihat demonstrasi guru dengan jelas

\section{DESAIN PENELITIAN TINDAKAN}

\section{Jenis Penelitian}

Jenis penelitian yang dipergunakan adalah Penelitian Tindakan Kelas atau Classroon Action Research (CAR).

\section{Waktu dan Tempat Penelitian}

Penelitian dilaksanakan pada tanggal 9 November 2013 sampai dengan 10 Desember 2013 yang diamati oleh 3 observer di SMK Negeri 2 Magetan, Jawa Timur. 

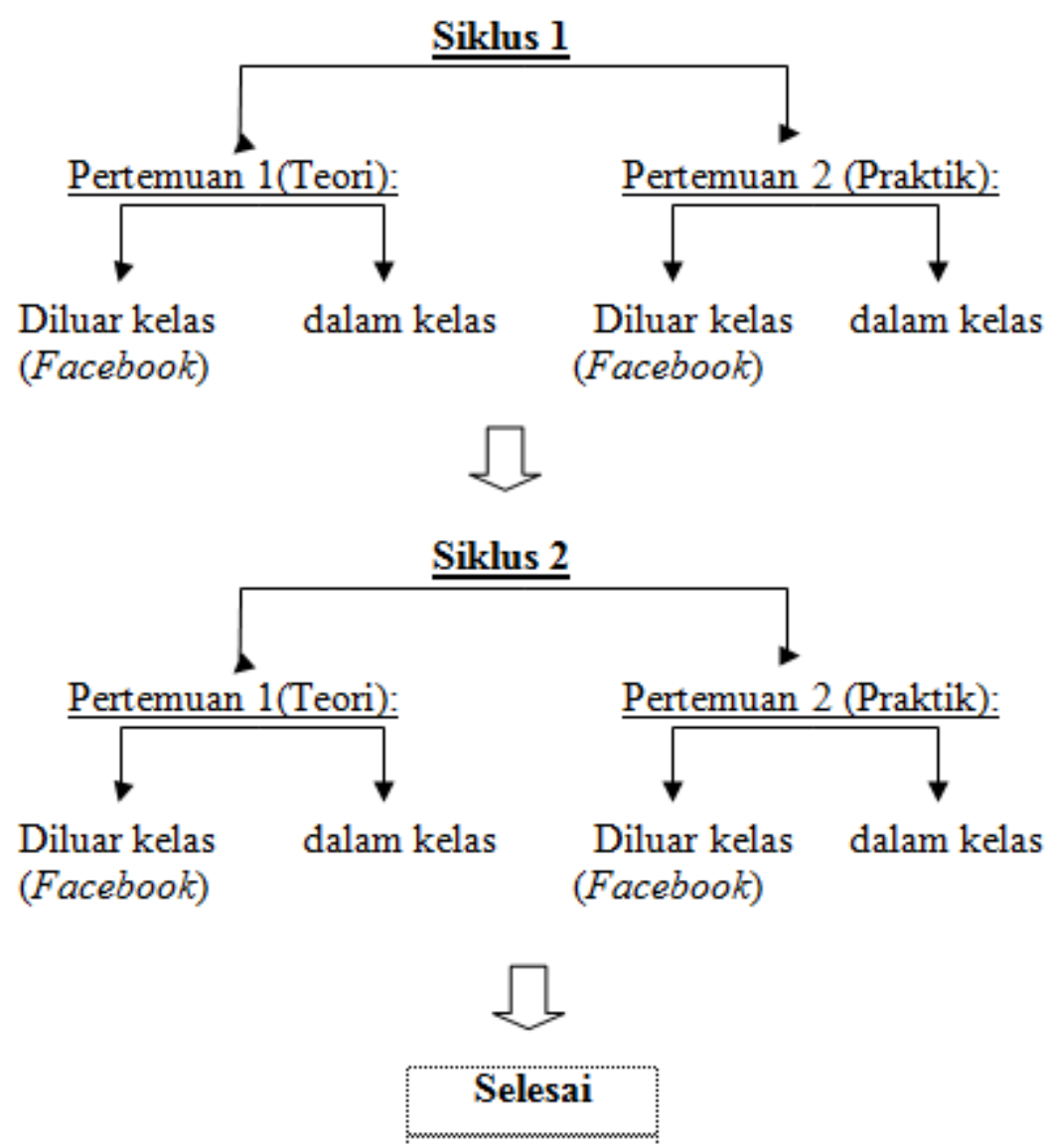

Gambar 4. Skema Desain Penelitian

\section{Target/Subjek Penelitian}

Penelitian difokuskan pada siswa kelas X Kompetensi Keahlian Jasa Boga A semester satu tahun pelajaran 2013-2014 dengan jumlah 22 siswa.

\section{Prosedur Tindakan}

Tindakan yang dilaksanakan mengacu pada penelitian tindakan kelas dengan tahap perencanaan, pelaksanaan, observasi dan evaluasi, refleksi. Perencanaan tindakan pembelajaran siklus I telah disiapkan sebelum pelaksanaan pembelajaran, sedangkan perencanaan tindakan pada siklus II disusun berdasarkan refleksi dan perbaikan tindakan siklus I. Langkah pembelajaran menggunakan media sosial dapat dilihat pada gambar 3 .

Desain penelitian dilaksanakan dalam dua siklus penelitian digambarkan pada skema yang dapat dilihat pada gambar 4 .

\section{Data, Intrumen, dan Teknik Pengumpulan Data}

Data yang dikumpulkan berupa data hasil belajar ranah sikap di kelas dan melalui Facebook dengan obsevasi, data ranah pengetahuan dengan tes tulis dan portofolio, data ranah keterampilan dengan penilaian kinerja.

\section{HASIL PENELITIAN DAN \\ PEMBAHASAN}

Penelitian dilaksanakan dalam 2 siklus dengan 2 kali pertemuan pada setiap siklusnya. Pada tiap pertemuan dipergunakan 2 sistem pembelajaran, yaitu pembelajaran melalui media jejaring sosial facebook dan pembelajaran di kelas.

Hasil tersebut menunjukkan bahwa terjadi peningkatan hasil belajar pada setiap siklus pembelajaran membuat gaarnish makanan dan 
Tabel 1. Peningkatan Kompetensi Ranah Sikap, Ranah pengetahuan, dan Ranah Keterampilan pada Pra Siklus, Siklus I, dan Siklus II

\begin{tabular}{lccc}
\hline \multirow{2}{*}{ Ranah Belajar } & \multicolumn{3}{l}{ Siswa yang kompeten } \\
\cline { 2 - 4 } & Pra Siklus & Siklus I & Siklus II \\
\hline Sikap melalui Facebook & - & $86,36 \%$ (Baik) & $100 \%$ (Sangat Baik) \\
Sikap di Kelas & - & $86,36 \%$ (Baik) & $100 \%$ (Sangat Baik) \\
Pengetahuan & $68,18 \%$ (cukup) & $77,27 \%$ (Baik) & $100 \%$ (Sangat Baik) \\
Keterampilan & $77,27 \%$ (Baik) & $100 \%$ (Sangat Baik) & $100 \%$ (Sangat Baik) \\
\hline
\end{tabular}

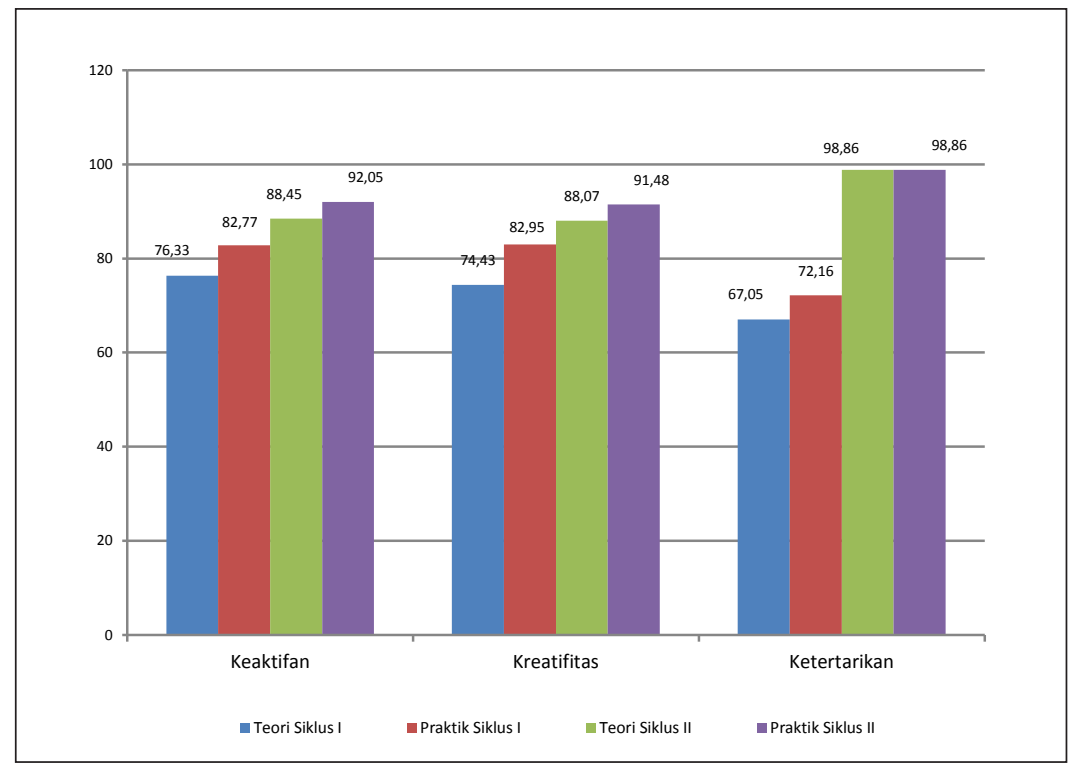

Gambar 5: Peningkatan indikator ranah sikap melalui Facebook pada siklus I dan II

minuman dengan pemanfaatan media sosial, baik pada ranah sikap, pengetahuan maupun keterampilan. Peningkatan tersebut sesuai dengan peningkatan seluruh indikator pada setiap ranah hasil belajar yang disajikan pada tabel 1 .

\section{Ranah Sikap melalui facebook}

Pada implementasi kurikulum 2013 yang berkaitan dengan pergeseran paradigma belajar abad 21, pembelajaran diarahkan untuk mendorong siswa mencari tahu dari berbagai sumber observasi dan bukan lagi diberi tahu oleh guru. Siswa dituntut untuk aktif mencari informasi dan pengetahuan melalui internet dengan tujuan untuk lebih menguatkan ilmu yang didapatkan sendiri.

Indikator ranah sikap melalui facebook yang digunakan untuk mengukur peran aktif siswa dalam media sosial dengan tujuan untuk membantu pencapaian tujuan belajar adalah
(1) Keaktifan siswa dalam facebook meliputi mengunduh, mengunggah, mengomentari, dan melihat; (2) Kreatifitas siswa dalam menggali informasi dari berbagai sumber; (3) Ketertarikan siswa terhadap media sosial sebagai media belajar siswa di luar tatap muka di dalam kelas.

Perbaikan yang dilakukan pada setiap pertemuan pembelajaran berdasarkan refleksi pada pembelajaran teori siklus I. Perbaikan yang dilakukan antara lain: (1) pemindahan ruang belajar ke ruang yang lebih dekat dengan pusat hostpot; (2) menyediakan fasilitas laptop di luar jam pembelajaran agar siswa bisa mengakses facebook dan media sosial lainnya secara bergantian; (3) mengupload video tutorial ke dalam akun grup.

Berikut ini merupakan grafik peningkatan hasil belajar seluruh indikator ranah sikap melalui media sosial pada seluruh siklus penelitian dapat dilihat pada gambar 5 . 
Pada hasil pembelajaran praktik siklus I, indikator kreatifitas dan ketertarikan siswa pada pemanfaatan media sosial dalam pembelajaran sudah mengalami peningkatan dari pembelajaran teori dengan kategori "sedang" untuk indikator kreatifitas, dan kategori "rendah" untuk indikator ketertarikan. Peningkatan tersebut masih perlu adanya motivasi dan dorongan kepada siswa agar siswa dapat lebih memanfaatkan media sosial dalam pembelajaran. Hal ini disebabkan pada saat praktik membuat garnish siswa belum percaya diri sehingga siswa mengaku kurang maksimal dalam mengakses akun grup, terutama dalam mengunggah hasil praktik siswa.

Peningkatan dengan kategori "sangat tinggi" pada indikator ranah sikap melalui facebook dari pembelajaran teori ke pembelajaran praktik berada pada sub indikator "Mengomentari pertanyaan atau status siswa lain" dan pada sub indikator "Menanyakan tentang materi/teknik membuat garnish". Hal ini merupakan kemajuan yang cukup signifikan bahwa siswa mulai mengalami kemajuan untuk berperan aktif dalam pembelajaran melalui facebook. Siswa sudah mulai merasa bahwa facebook juga dapat dimanfaatkan dalam pembelajaran.

Tindakan yang dilakukan pada siklus II menunjukkan hasil peningkatan pada ranah sikap melalui facebook dengan hasil akhir pada siklus II yang terdiri dari keaktifan, kreatifitas, dan ketertarikan siswa dengan kategori sangat baik. Dengan demikian keberadaan media sosial dalam pembelajaran sangat menarik perhatian siswa dan dapat dijadikan sebagai sarana belajar di luar jam tatap muka. Hal ini sesuai dengan data peningkatan indikator hasil belajar ranah sikap melalaui media sosial dari siklus I menuju siklus II dimana skor peningkatan ranah sikap melalui facebook dengan kategori "Sangat Tinggi" terdapat pada indikator ketertarikan siswa.

Hal ini juga dibuktikan dengan antusiasme siswa yang ditunjukkan oleh komentar pada akun grup facebook dengan rata-rata pernyataan ingin menggunakan facebook untuk sarana belajar pada semua mata pelajaran. Ketertarikan yang ditunjukkan siswa merupakan modal yang sangat baik untuk mencapai tujuan pembelajaran.
Keberadaan akun facebook grup vokasi 1 dalam pembelajaran membuat garnish makanan dan minuman menunjukkan hasil belajar yang lebih kompeten dari pada pembelajaran sebelumnya. Siswa dapat terus berinteraksi mengenai pelajaran meskipun pembelajaran sudah di luar jam tatap muka. Disamping itu, siswa dilatih untuk menghargai hasil karya orang lain dengan memberi komentar ataupun pertanyaan kepada siswa lain. Namun siswa masih perlu diberi motivasi untuk berani dan percaya diri dalam mengungkapkan pendapat atau saran mengenai pelajaran melalui facebook.

Selama ini siswa hanya terbiasa memberi komentar mengenai hal-hal umum dan bersifat nonedukasi. Hal ini perlu diarahkan kepada siswa agar mengindari sikap-sikap dan perilaku yang kurang baik melalui facebook. Tujuan lainnya adalah melatih siswa untuk memanfaatkan media sosial guna mendapatkan ilmu pengetahuan dan teknologi dari media sosial dengan lebih cepat dan efisien. Hal ini dikuatkan oleh Badan Standar Nasional Pendidikan (2010, p.20) bahwa "Dalam konteks pemanfaatan teknologi informasi dan komunikasi di dunia pendidikan, telah terbukti semakin menyempitnya dan meleburnya faktor "ruang dan waktu" yang selama ini menjadi ranah penentu kecepatan dan keberhasilan penguasaan ilmu pengetahuan oleh umat manusia."

\section{Ranah Sikap di Kelas}

Berikut ini merupakan peningkatan hasil belajar ranah sikap pada setiap siklus dapat dilihat pada gambar 6 .

Secara umum, hasil belajar ranah sikap pada setiap pertemuan mengalami kenaikan. Setiap indikator ranah sikap di kelas pada pembelajaran teori mengalami peningkatan. Pada pelaksanaan pembelajaran praktik siklus I, pada indikator keaktifan sub indikator "Bertanya dengan aktif" dan "Memperhatikan penjelasan guru" dengan kategori "Sangat tinggi". Hal ini menunjukkan peningkatan yang baik pada indikator keaktifan siswa dalam pembelajaran. Perbaikan yang dilakukan sudah menunjukkan hasil yang lebih baik.

Pada siklus II terjadi peningkatan indikator kemandirian dari siklus I dengan kategori 


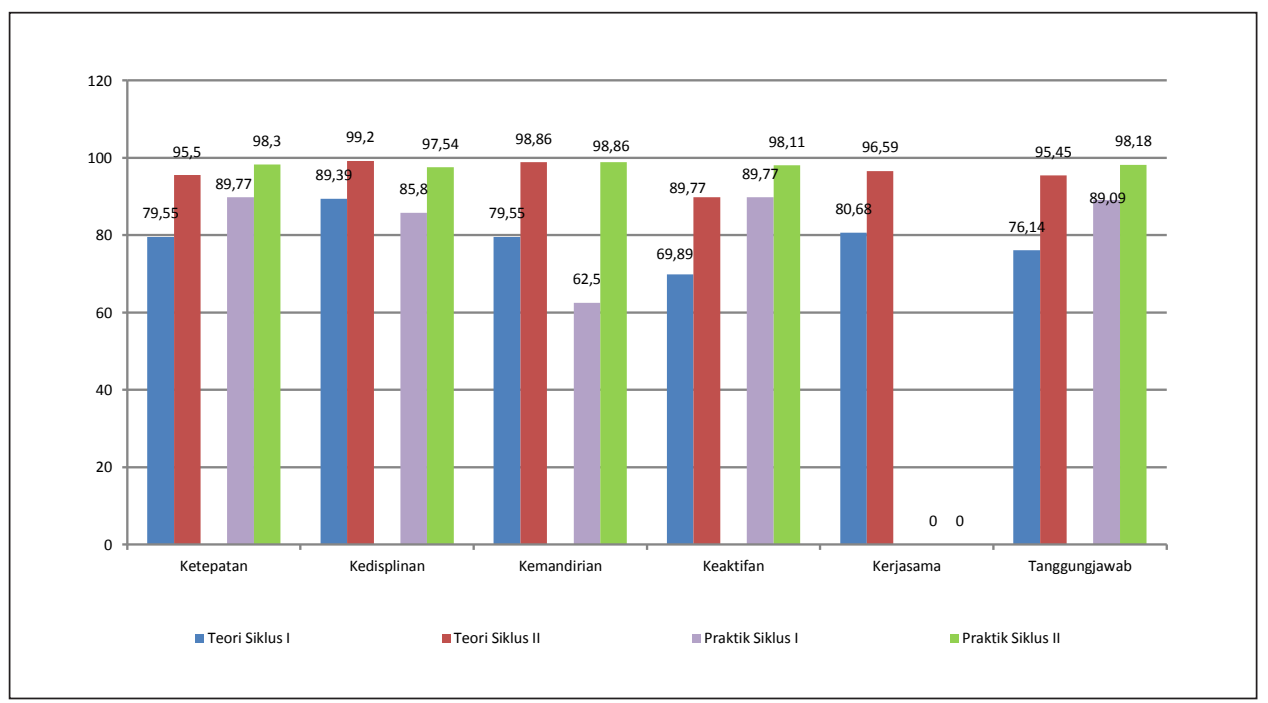

Gambar 6: Peningkatan indikator ranah sikap di Kelas pada siklus I dan II

"Sangat Tinggi". Hal ini menunjukkan bahwa keberadaan media sosial dapat meningkatkan kemandirian siswa dalam mengejakan evaluasi atau praktik pembelajaran.

Media sosial membantu siswa belajar secara mandiri di luar jam tatap muka di kelas, namun siswa masih tettap dapat berkomunikasi dengan guru atau siswa lainnya melalui media sosial. Siswa dapat memperdalam ilmu yang didapatkan dari guru dengan mengembangkan ilmu tersebut melalui referensi yang dapat diperoleh melalui media sosial. Ilmu yang dikembangkan kemudian dapat disimpulkan menjadi pengetahuan yang mendalam dan dapat diaplikasikan dalam kehidupan sehari-hari.

Pada pengembangan kurikulum 2013 terdapat penyempurnaan pola pikir dari kurikulum lama dengan penguatan proses pembelajaran dengan pendekatan ilmiah (scientific approach) melalui kegiatan mengamati (observing), menanya (questioning), menalar (associating), mencoba (experimenting), membentuk jejaring (networking) untuk semua mata pelajaran. Pendekatan tersebut menuntut siswa untuk lebih aktif dan tidak terbatas hanya pada menerima materi dari guru saja, namun siswa dituntut untuk menemukan sendiri, mengembangkan dan menganalisa materi yang sedang dipelajari. Dengan demikian respon siswa sangat menentukan keberhasilan pembelajaran sehingga ranah sikap yang bertujuan siswa "tahu mengapa" dapat tercapai.
Melalui pemanfaatan facebook atau media sosial lainnya siswa telah membentuk jejaring dalam pembelajaran dengan aktifitas mengamati materi, berinteraksi tanya jawab dengan guru dan siswa lain, menalar apa yang terkandung dalam materi pelajaran tersebut, dan mencoba menggali lebih jauh dengan browsing dari berbegai sumber. Dengan demikian facebook saat ini tidak hanya digunakan untuk kepentingan bersosialisasi, akan tetapi dapat dipergunakan untuk pembelajaran secara online di luar jam tatap muka di kelas. It is important to note that the students revealed that they use the Internet not only for social purposes, but for study purposes as well as for Participating in online communities (Eteokleous, 2012, p.371).

Guru dan siswa dapat memanfaatkan facebook untuk beraktifitas belajar sama dengan di sekolah akan tetapi dengan ruang dan waktu yang lebih bebas dan tidak terbatas. Pengalaman yang siswa peroleh akan lebih mendalam dan tertanam kuat dalam ingatan siswa sehingga pemahaman siswa terhadap materi yang sedang dibahas akan semakin dalam.

\section{Ranah Pengetahuan}

Perbandingan hasil belajar indikator ranah pengetahuan pada Siklus I dan Siklus II dapat dilihat gambar 7.

Gambar 7 menunjukkan adanya peningkatan hasil belajar ranah pengetahuan pada siklus 


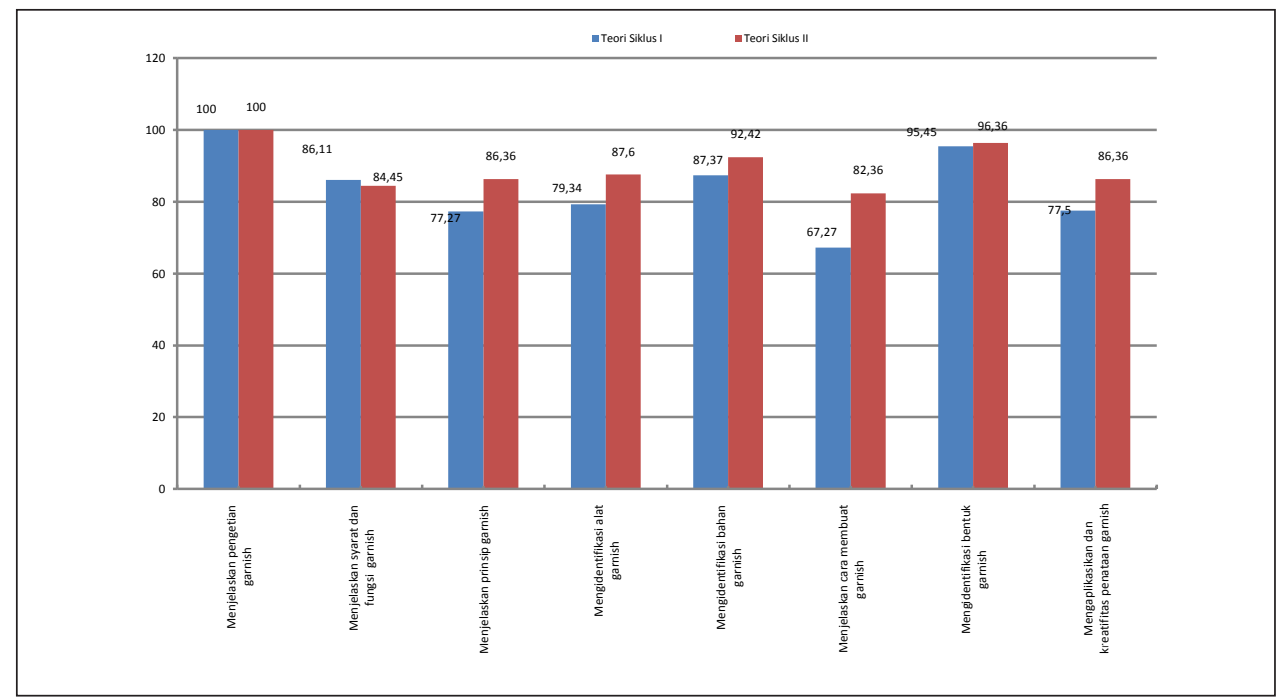

Gambar 7. Peningkatan indikator ranah penge-tahuan pada siklus I dan II

I dan siklus II. Hampir semua indikator ranah pengetahuan mengalami peningkatan hasil belajar siswa, namun pada indikator "Menjelaskan syarat dan fungsi garnish" mengalami penurunan. Hal ini disebabkan pada pembelajaran praktik siklus II terdapat satu siswa yang mengalami sakit sehingga hasil belajar siswa tersebut kurang maksimal.

Pembelajaran pada siklus II tetap memanfaatkan facebook sebagai sarana belajar di luar kelas maupun pada saat mengerjakan tugas kelompok. Siswa terus dimotivasi untuk memanfaatkan media sosial secara optimal agar siswa lebih dapat menguasai materi yang diberikan. Disamping itu, perbaikan yang dilakukan adalah penayangan video tutorial yang dapat diamati siswa. Dengan memiliki gambaran yang lebih jelas, hasil belajar siswa ranah pengetahuan siklus II pada indikator "Menjelaskan cara membuat garnish" meningkat dengan kategori "Sangat Tinggi". Siswa memiliki pemahaman dan gambaran yang lebih jelas terhadap cara membuat garnish. Beberapa teknik yang harus diketahui siswa dapat diakomodir dengan keberadaan media sosial.

Melalui facebook siswa dapat mengambil materi yang diberikan oleh guru. Apabila ada yang belum jelas mengenai materi tersebut, siswa dapat mengkomunikasikannya melalui forum chat secara langsung dengan guru atau melalui status yang akan direspon oleh guru. Disamping itu siswa dapat membangun kembali materi yang didapatkan dengan browsing melalui media sosial lainnya, seperti google, wiki, atau bahkan YouTube yang akan menampilkan video-video mengenai materi yang mereka butuhkan. Pengetahuan yang telah diperdalam dengan bantuan media sosial tersebut akan meningkatkan pemahaman siswa mengenai pelajaran yang sedang mereka pelajari. Hal ini sejalan dengan pendapat Davies (1998, p.183) mengenai paradigma baru dalam pembelajaran yang bersifat terbuka, bahwa:

The main focus of this paradigm is on the processes of knowing and the learner's organisation of meaning into larger schemes of knowledge and experience. This kind of enquiry has led to a view of learning in which the structuring of knowledge and the processes by which it is acquired are seen to be fundamental to the development of understanding. For the teacher, the essential problem is to understand the logic of the learner's processes of knowing - to understand how the learner interprets and accommodates new knowledge. The relationship between the structures of meaning which the learner habitually uses and the structures which are presented by the teacher is critical.

Dijelaskan lebih lanjut Moskal, Dziuban, \& Hartman (2010, p.65)

Adult learners in online classes can have many rich Web 2.0 learning resources available to them. The convenience and 
Tabel 2. Paradigma Pembelajaran Modern menurut Cheng

\begin{tabular}{|c|c|}
\hline New CMI-Triplization Paradigm & Traditional Site-Bounded Paradigm \\
\hline Individualized Learning & Reproduces Learning \\
\hline - Student is the Centre of Education & - Student is the Follower of Teacher \\
\hline - IndividualizedPrograms & - $\quad$ Standard Programs \\
\hline - $\quad$ Self-Learning & - $\quad$ Absorbing Knowledge \\
\hline - $\quad$ Self-Actualizing Process & - $\quad$ ReceivingProcess \\
\hline - $\quad$ Focus onHowto Learn & - $\quad$ Focus on How to Gain \\
\hline - $\quad$ Self Rewarding & - $\quad$ ExternalRewarding \\
\hline Localized and Globalized Learning & Institution-Bounded Learning \\
\hline - $\quad$ Multiple Sources of Learning & - $\quad$ Teacher-Based Learning \\
\hline - $\quad$ NetworkedLearning & - $\quad$ Separated Learning \\
\hline - $\quad$ Lifelong and Everywhere & - $\quad$ Fixed Period and Within Institutions \\
\hline - Unlimited Opportunities & - $\quad$ Limited Opportunities \\
\hline - $\quad$ World-Class Learning & - $\quad$ Site-Bounded Learning \\
\hline - $\quad$ Local and International Outlook & - $\quad$ Mainly Institution-basedExperiences \\
\hline
\end{tabular}

flexibility that motivates them meshes perfectly with their ability to collect resources in a retrievable system, write cooperative$l y$, form and participate in social communities, share their material and resources worldwide, remix resources into new content, instantly communicate around the world and enter alternative realities.

Fokus utama dari paradigma baru terletak pada proses pengetahuan dan pengorganisasian pemahaman dari pelajar ke dalam bentuk pengetahuan dan pengalaman yang lebih besar. Jenis pembelajaran inquiry ini telah mengarah kepada sebuah pandangan tentang pembelajaran dimana struktur dari pengetahuan dan proses yang didapatkan merupakan inti dalam pengembangan dari pemahaman. Bagi guru, masalah utama adalah memahamkan secara logika tentang proses mengetahui para pelajar, untuk memahamkan bagaimana pelajar menterjemahkan dan menyesuaikan diri terhadap pengetahuan baru tersebut.

Hubungan antara struktur pengetahuan yang digunakan siswa sehari-hari dan struktur pengetahuan yang dipaparkan oleh guru merupakan masalah utama. Dalam hubungannya dengan mengembangkan pengetahuan siswa, pendidikan menjadi bagian dari multi dimensi jaringan artinya bahwa institusi sekolah di- mungkinkan berhubungan dengan cara yang berbeda dan dalam arah yang bervariasi.

Pembelajaran dapat dilakukan kapanpun dan dimanapun dan tidak dapat selamanya dipaksa dengan batasan-batasan tradisional yang diragukan relevansinya dengan kepentingan modern. Universitas dan penyelenggara pendidikan lainnya harus menjadi sistem yang terbuka. Hal ini tentu saja bukan merupakan batasan-batasan fisik dari kampus.

Sistem terbuka yang dimaksud adalah sebuah sistem atau pembelajaran yang bersifat jejaring atau sistem yang terhubung dengan sistem lain secara cepat. Sistem ini disebut dengan online dimana semua sistem, institusi ataupun pembelajaran dapat saling berinteraksi dengan cepat.

Pelajar yang berusia dewasa dalam pembelajaran online dapat memiliki banyak keuntungan tentang keberadan sumber belajar web 2.0. Kenyamanan dan keluwesan yang memotivasi mereka menjerat dengan sempurna dengan kemampuan untuk menggabungkan sumber-sumber ke dalam sebuah sistem yang dapat diperbaiki kembali, menulis secara bersamasama, membentuk dan berpartisipasi dalam komunitas sosial, berbagi materi dan sumber dari seluruh dunia, menggabungkan kembali sumber-sumber ke dalam konten yang baru, 


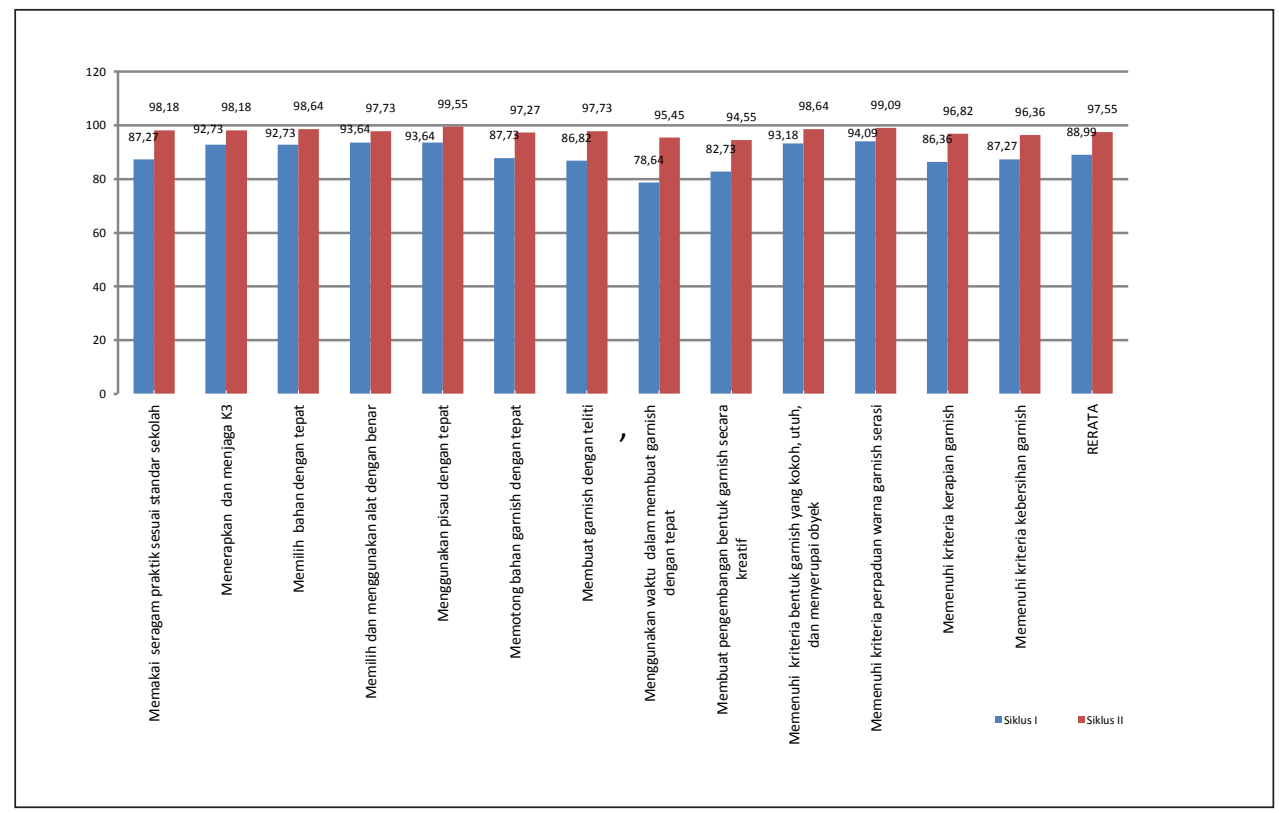

Gambar 8: Peningkatan indikator ranah kete-rampilan pada siklus I dan II

berkomunikasi secara cepat ke seluruh penjuru dunia dan berperan dalam dunia nyata yang penuh pilihan.

Pendidikan yang diselenggarakan dengan paradigma terbuka atau secara online merupakan sarana yang bertujuan untuk mengembangkan pengetahuan dan keterampilan siswa. Proses dalam memperdalam dan memaknai pengetahuan yang didapatkan akan menjadi sebuah proses pembelajaran yang berkualitas. Siswa tidak akan lagi menghadapi batasan-batasan dalam menggali pengetahuan baru. Siswa dapat dengan leluasa mengembangkan pengetahuan dan membentuk pengetahuan baru, dan bahkan sampai siswa dapat menemukan relevansinya dengan kehidupan sehari-hari. Proses inilah yang menjadi tujuan pendekatan scientific dari kurikulum 2013 dan merupakan metode pembelajaran modern serta mengikuti perkembangan jaman sesuai dengan paradigma pembelajaran yang disampaikan oleh Cheng (2005, p.29) pada tabel shift of learning yang merupakan konteks kecerdasan majemuk yang mengacu pada tiga arah pembelajaran yaitu individual, lokal, dan global (Cheng, 2005, pp.26-27).

Konsep New Paradigm CMI-Triplization ini menerangkan bahwa siswa memiliki ciri-ciri sebagai pusat pembelajaran, program secara mandiri, pembelajaran mandiri, proses aktualisasi secara mandiri, pembelajaran berbasis jaringan internet, dilaksanakan dimana saja dan kapan saja, kesempatan yang tidak terbatas, pembelajaran kelas dunia, berpandangan secara lokal dan internasional, serta menggunakan dberbagai sumber belajar.

\section{Ranah Keterampilan}

Indikator pada ranah keterampilan membuat garnish makanan dan minuman dinilai pada saat siswa membuat garnish mulai dari persiapan, proses, sampai adanya produk yang dihasilkan. Perbandingan hasil belajar ranah keterampilan pada siklus I dan siklus II dapat dilihat pada gambar 8 .

Pembelajaran kompetensi membuat garnish makanan dan minuman sebelum tindakan menunjukkan siswa belum mampu menggunakan waktu dalam membuat garnish dengan tepat. Pada ranah keterampilan siklus I tersebut juga diperoleh peningkatan indikator dari hasil belajar pra siklus dengan kategori "Sangat tinggi" yaitu pada indikator "Menggunakan pisau dengan tepat". Hal ini menunjukkan bahwa pembelajaran dengan menggunakan media sosial mampu meningkatkan keterampilan siswa dalam menggunakan pisau garnish. Namun demikian, ketercapaian pada indikator 
"Menggunakan waktu dalam membuat garnish dengan tepat" masih rendah yaitu mencapai $78,64 \%$.

Hal ini disebabkan siswa belum memahami teknik membuat garnish dengan baik. Siswa tersebut belum memiliki pemahaman yang sama mengenai teknik membuat garnish seperti pemahaman siswa lainnya sebagai akibat posisi duduk dan jarak pandang yang kurang dekat dengan demonstrasi yang dilakukan oleh guru. Siswa mengalami kesulitan membuat garnish saat praktik. Siswa lebih sering berpindah tempat untuk mencari informasi mengenai teknik yang akan digunakan sehingga suasana praktik menjadi tidak tenang dan kurang kondusif.

Demonstrasi yang baik adalah demonstrasi yang dapat diamati oleh seluruh peserta dengan daya dukung sarana yang memadai. Daya dukung tersebut antara lain: ruangan yang luas, pencahayaan yang cukup, terdapat kaca besar di belakang bagian atas demonstrator, jarak antara demonstrator dan peserta yang terjangkau. Sementara itu, daya dukung ruang praktik Lab. 1 Jasa Boga di SMK Negeri 2 Magetan belum memenuhi standar sebagai ruang demonstrasi. Hal ini berpengaruh pada hasil belajar ranah keterampilan. Sebagai upaya perbaikan pembelajaran praktik siklus I maka pada pertemuan berikutnya dipergunakan video tutorial untuk mendukung dan mengoptimalkan pemahaman siswa terhadap materi yang diberikan guru.

Berdasarkan pelaksanaan pembelajaran praktik pada siklus I maka diadakah perbaikan lagi pada pembelajaran praktik siklus II dengan memanfaatkan video tutorial yang diunggah melalaui facebook. Dan hasil belajar ranah keterampilan tersebut semakin meningkat dengan nilai rata-rata mencapai 97,50. Pada indikator "Menggunakan waktu dalam membuat garnish dengan tepat" meningkat $16,81 \%$ dengan kategori "Sangat Tinggi" yang ditunjukkan pada gambar 8. Siswa lebih siap dalam melaksanakan praktik membuat garnish dengan bekal video yang telah diperoleh melalui media sosial sehingga siswa memiliki pemahaman yang baik mengenai cara membuat garnish. Dengan demikian waktu yang semula menjadi keterbatasan dalam mencapai tujuan pembelajaran maka dapat diatasi dengan adanya pembelajaran melalui Facebook.
Siswa dapat mengamati cara membuat garnish makanan dan minuman tanpa membawa bahan dan alat yang nyata, akan tetapi melalui video siswa dapat mengamati teknik-teknik membuat garnish seperti benda nyata dengan tanpa dibatasi ruang dan waktu. Teknik-teknik yang diperlihatkan dalam video dapat dilihat secara slow motion atau dihentikan pada bagian tertentu sehingga teknik-teknik yang memerlukan pengamatan khusus dapat dipahami oleh siswa.

Melalui media sosial siswa juga berinteraksi dengan guru dan siswa lain membahas tentang video yang diunggah. Pertanyaan mengenai teknik-teknik membuat garnish maupun bahan dan alat yang belum jelas dibahas dan dikomentari. Siswa juga dapat mencari literatur video lain dan dapat menunggah ke dalam grup. Hal ini sejalan dengan pendapat Smaldino (2008, p.310) bahwa

Videos are available on almost any topic and for all types of learner in all the domains of instruction - cognitie, affective, motor skill, and interpersonal. They can take the learner almost anywhere, extending students' interest beyond the walls of the classroom. Object too large to bring into classroom can be studied as well as those too small to see with the naked eye.

Video dapat dipergunakan pada semua materi dan untuk semua jenis pelajar dengan berbagai bidang ilmu baik pengetahuan, sikap, keterampilan, dan perseorangan. Video dapat dipergunakan para pelajar hampir dimanapun, sepanjang ketertarikan para pelajar diluar jam tatap muka di kelas. Benda-benda nyata dalam video tersebut terlalu besar untuk dibawa ke dalam kelas tetapi bisa dipelajari sama baiknya dengan benda-benda yang lebih terlihat kecil dengan mata biasa.

Benda-benda yang terdapat dalam video merupakan obyek pengganti benda aslinya. Dengan menggunakan video tersebut siswa dapat belajar secara mandiri dan dilakukan secara berulang-ulang sehingga skill yang terbentuk akan semakin kuat dan kompeten.

$\begin{aligned} & \text { Pemanfaatan } \\ & \text { Pembelajaran }\end{aligned}$ Kompetensi
Garnish Makanan dan Minuman


Pemanfaatan facebook dan media sosial lainnya dalam pembelajaran dapat membuat siswa seolah rajin belajar. Sebagaimana siswa sering mengunjungi facebook untuk kepentingan sosial, maka siswa akan semakin sering juga untuk mengunjungi akun pembelajaran dan sumber-sumber belajar lainnya. Server atau admin akan menampilkan pemberitahuan setiap status yang diunggah guru. Hal ini akan menarik minat siswa mengunjungi akun pembelajaran. Dengan demikian interaksi pembelajaran akan terjadi, minimal siswa akan melihat status pembelajaran yang disampaikan oleh guru.

Hal ini sesuai dengan pendapat Baker dalam Eteokleous (2012, p.366) bahwa "Facebook is a network that connects students with other students, indirectly creating a learning community - a vital component of student education". Dijelaskan lebih lanjut bahwa

Facebook's numerous features such as email, bulletin boards, instant messaging, video and picture posting and applications download supplement serve the educational function of enabling communication, collaboration and sharing between students and faculty." (Eteokleous, 2012, p.366)

Dijelaskan bahwa facebook merupakan sebuah jejaring yang menghubungkan antara siswa yang satu dengan siswa lainnya, secara tidak langsung membangun sebuah komunitas belajar yang merupakan sebuah komponen penting pendidikan siswa. Beberapa fasilitas pada facebook seperti email, papan pemberitahuan, pesan singkat, pengiriman video dan gambar, dan beberapa aplikasi tambahan untuk pengunduhan menyajikan fungsi-fungsi yang berhubungan dengan pendidikan yang dapat digunakan untuk berkomunikasi, berkolaborasi, dan berbagi antara siswa dan pendidik.

Siswa dan para pendidik saat ini sudah mulai memanfaatkan media sosial seperti facebook untuk berinteraksi dalam konteks pembelajaran. Guru dapat berbagi materi, gambar, video dan sedangkan siswa dapat mengunduhnya. Siswa dapat bertanya atau mengomentari materi-materi pelajaran yang diunggah guru. Siswa dapat mencari literatur materi dari sumber-sumber media sosial lainnya untuk menunjang dan memperdalam pengetahuan yang sedang dipelajarinya.

Dijelaskan oleh Steve Hargadon (2009, p.8) bahwa "A new social learning network where educators can connect with colleagues, share content, build online portfolios, access resources, atend events, and collaborate in real-time." Dijelaskan lebih lanjut bahwa

With generic social networking tools applied to education, it is possible to search for and find forums and other resources that appeal to like minded individuals, or to put queries out there in hopes that someone will respond, but these are not especially efective at really finding those with specifically common interests (Hargadon, 2009, p.9)

Sebuah jejaring sosial pembelajaran merupakan wadah dimana para pengajar dapat berhubungan dengan rekan kerja, berbagi materi, membuat porotofolio secara online, mengakses sumber-sumber belajar, menghadiri pertemuan secara online, dan bekerjasama dalam waktu yang nyata. Perangkat jejaring sosial yang dipergunakan untuk pembelajaran sangat sulit dicari dan ditemukan forum atau sumber yang berpola individual, atau meragukan tentang respon seseorang, tetapi hal ini tidak efektif khususnya bagi peminat umum diluar pembelajaran.

Dengan pola pembelajaran yang dilakukan oleh para pengajar melalui facebook atau media sosial lainnya maka siswa sebagai tujuan pembelajaran juga dapat melakukan hal yang sama. Siswa dapat menggunakan media sosial untuk berhubungan dengan guru atau siswa lain, berdiskusi, mengunduh dan berbagi materi, mengerjakan tugas dan membuat portofolio, mengakses sumber belajar, dan bahkan dapat membangun rasa percaya diri dan kebanggaan atas hasil karya yang ditampilkan dan diapresiasi oleh khalayak umum.

Dengan berbagai aktifitas tersebut, diharapkan kegiatan belajar akan lebih menyenangkan dan mencapai hasil yang kompeten. Sesuai dengan tujuan dikembangkannya kurikulum 2013 dan tuntutan pendidikan abad XXI bahwa pendidikan tidak lagi terbelenggu 
oleh ruang kelas, siswa lebih aktif dan mandiri, sinergitas antar bidang ilmu pengetahuan yang akan melahirkan siswa yang produktif, inovatif, dan kreatif melalui sentuhan proses pembelajaran ranah sikap, pengetahuan dan keterampilan yang digambarkan pada kerangka pembelajaran abad ke-21 yang tertuang dalam Framework for 21st Century Learning (http:// www.p21.org/about-us/p21-framework) dengan konsep yang ditunjukkan pada gambar 9.

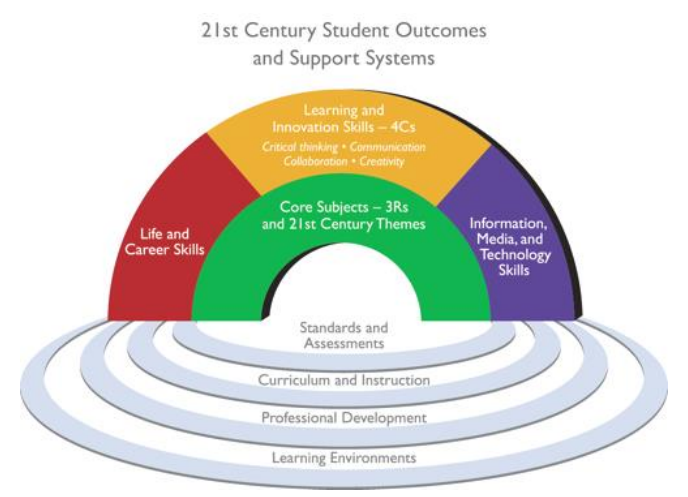

Gambar 9. Kerangka Pembelajaran Abad ke-21 (http://www.p21.org/about-us/p21-framework)

Kerangka tersebut menyajikan tentang pandangan yang menyeluruh terhadap pengajaran dan pembelajaran abad ke-21dimana elemen kunci dari pembelajaran abad ke-21 adalah karakter, pengetahuan dan keahlian siswa harus dikuasai untuk berhasil dalam pekerjaan dan kehidupan, yang merupakan perpaduan antara konten pengetahuan, keterampilan khusus, keahlian dan kemahiran. Sedangkan pelaksanaan keterampilan memerlukan pengembangan pengetahuan terhadap inti pelajaran akademis dan pemahaman antara semua siswa. Siswa yang dapat berpikir kritis dan berkomunikasi secara efektif harus mampu membangun pengetahuan yang diperoleh. Dalam konteks instruksi pengetahuan inti, siswa juga harus belajar keterampilan yang diperlukan untuk kesuksesan dalam kehidupan di dunia saat ini, seperti berpikir kritis, memecahkan masalah, berkomunikasi dan berkolaborasi.

Hal ini juga sesuai dengan tujuan pendidikan nasional dalam paradigma pendidikan nasional abad XXI yang dikukuhkan oleh BSNP (2010, p.39) yaitu:
Pendidikan Nasional abad XXI bertujuan untuk mewujudkan cita-cita bangsa, yaitu masyarakat bangsa Indonesia yang sejahtera dan bahagia, dengan kedudukan yang terhormat dan setara dengan bangsa lain dalam dunia global, melalui pembentukan masyarakat yang terdiri dari sumber daya manusia yang berkualitas, yaitu pribadi yang mandiri, berkemauan dan berkemampuan untuk mewujudkan cita-cita bangsanya.

Berdasarkan analisa dari seluruh data pada tabel dan gambar diatas dapat diketahui bahwa pembelajaran dengan memanfaatkan facebook sebagai sarana berkomunikasi dan pembelajaran di luar kelas dapat meningkatkan hasil belajar siswa pada ranah sikap, ranah pengetahuan, dan ranah keterampilan. Hal ini juga didukung dengan menayangkan video tutorial walaupun masih perlu adanya pengamatan secara berulang-ulang oleh siswa.

Pencapaian hasil belajar tersebut dapat dilihat pada peningkatan setiap indikator semua ranah hasil belajar pada setiap pertemuan. Ketertarikan siswa terhadap pembelajaran dengan menggunakan facebook dan media sosial lainnya pada siklus II mencapai $98,86 \%$. Hal ini menunjukkan bahwa keberadaan media sosial dalam pembelajaran sudah mulai disukai siswa. Media sosial seperti facebook yang semula hanya dipergunakan siswa untuk kepentingan sosial dan hiburan, saat ini siswa sudah mulai menggunakan facebook untuk belajar dan berbagi ilmu. Dengan demikian perlu adanya dukungan sarana dan prasarana yang memadai. Daya dukung sarana tersebut diharapkan dapat memperlancar kegiatan belajar mengajar di kelas maupun di luar kelas sehingga tujuan pembelajaran dapat dicapai secara optimal.

Hasil belajar yang didapatkan pada ranah sikap, pengetahuan dan keterampilan akan bersinergi dalam mencapai kompetensi yang harus dikuasi siswa melalui penilaian kinerja atau performance test yang akan mengukur kemandirian, kreatifitas, kedisplinan, ulet, dan tanggung jawab siswa dalam menghasilkan sebuah karya atau produk berkaitan sangat erat 
dengan pengetahuan yang diperoleh. Hal ini sesuai dengan petunjuk teknis penilaian hasil belajar sekolah menengah kejuruan (direktorat pembinaan sekolah menengah kejuruan, 2008, p.15) bahwa tes performance mengharuskan siswa untuk menunjukkan cara kerja ketrampilan yang telah dipelajari dan memperagakan keahliannya tersebut sesuai dengan keadaan dan kondisi yang sama atau menyerupai dunia kerja sebenarnya. Hal ini juga sesuai dengan pengembangan kurikulum 2013 dimana indikator ranah keterampilan yang sesuai dengan Standar Kompetensi Lulusan yaitu menggunakan, mengurai, merangkai, memodifikasi, membuat, dan mencipta (Kemdikbud, 2012: p.30).

Berdasarkan pernyataan diatas maka beberapa target yang akan dicapai melalui penilaian kinerja yaitu: (1) sikap, yaitu hasil belajar siswa yang menunjukkan tentang tingkah laku, minat, nilai, motivasi dan konsep diri siswa selama dalam kegiatan pembelajaran; (2) pengetahuan, yaitu hasil belajar siswa yang menunjukkan sejauh mana pemahaman siswa terhadap aspek-aspek yang terdapat dalam keterampilan yang dipelajari; (3) penalaran, yaitu hasil belajar siswa yang menunjukkan siswa mampu mengaplikasikan pengetahuan dalam konteks memecahkan sebuh permasalahan; (4) skill, yaitu hasil belajar siswa yang menunjukkan kemampuan siswa dalam menguasai sebuah keahlian; (5) produk, yaitu hasil karya siswa sebagai wujud keahlian yang telah dikuasainya.

Target pembelajaran tersebut tidak dapat dilepaskan dari keberadaan daya dukung Facebook dan media sosial lainnya yang dipergunakan sebagai media pembelajaran. Pemanfaatan facebook sebagai jejaring yang digunakan siswa dalam menguatkan ketiga ranah pembelajaran tersebut akan membantu siswa dalam mengoptimalkan keberhasilan siswa dalam pembelajaran. Hal ini dijelaskan oleh Stanciau, A., Mihai, F., \& Aleca (2012, p.61) bahwa Facebook sebagai sebuah alat berharga yang dapat digunakan dalam pendidikan antar lain: (1) guru dapat membuat daftar siswa dan mengelola grup siswa sesuai dengan tema mata pelajaran; (2) bertukar informasi melalui link, foto atau multimedia yang berhubungan dengan topik tertentu; (3) membuat peninjauan dan mengukur umpan balik; (4) menggunakan percakapan online untuk komunikasi langsung antara siswa dan guru; (5) mengumumkan ujian, jadwal pertemuan tatap muka; menggabungkan Facebook dengan layanan kolaboratif lainnya yang disediakan oleh aplikasi lainnya; menggunakan Facebook sebagai sebuah pelengkap untuk program eLearning.

\section{SIMPULAN DAN SARAN}

\section{Simpulan}

Media sosial dimanfaatkan dalam pembelajaran baik di dalam kelas maupun di luar kelas. Pembelajaran di luar kelas menggunakan Facebook dan pembelajaran di dalam kelas menggunakan metode diskusi dengan menggunakan sumber belajar media sosial, demonstrasi, dan menggunakan Facebook sebagai sarana siswa dalam mengomunikasikan hasil belajar, serta ketercapaian kompetensi yang didapatkan pada siklus I dengan kategori "baik"dan ketercapaian pada siklus II dengan kategori "sangat baik. Manfaat media sosial dalam pembelajaran dapat meningkatkan interaksi siswa, lebih mandiri, kreatif, percaya diri, dan lebih menghargai pendapat orang lain.

\section{Saran}

Untuk meningkatkan kompetensi siswa sebaiknya guru mengupayakan pembelajaran yang menarik dan dengan berbagai metode pembelajaran. Dan guna menunjang hal tersebut sekolah sebaiknya sarana pra sarana IT mulai dipertimbangkan keberadaanya, mengingat perkembangan teknologi yang semakin cepat.

\section{DAFTAR PUSTAKA}

Badan Standar Nasional Pendidikan. (2010). Paradigma pendidikan nasional abad $X I$. Jakarta: Departemen Pendidikan Nasional

Cavazza, F. (2014). Social media landscpae 2014. Diakses tanggal 23 juni 2014, dari www.fredcassava.net 
Cheng, Y. C. (2005). New paradigm for reengineering education: globalization, localization and individualization. Dordrecht, The Netherlands: Springer.

Depdiknas. (2003). Undang-Undang RI Nomor 20 Tahun 2003, tentang Sistem Pendidikan Nasional

Depdiknas. (2006). Peraturan Pemerintah RI Nomor 23 tahun 2006, tentang Standar Kompetensi Lulusan.

Direktorat pembinaan sekolah menengah kejuruan, Direktorat jenderal manajemen pendidikan dasar dan menengah, Departemen pendidikan nasional (2008). Petunjuk teknis penilaian hasil belajar sekolah menengah kejuruan.

Direktorat pembinaan sekolah menengah kejuruan, Direktorat jenderal pendidikan menengah, Kementerian pendidikan dan kebudayaan. (2013). Petunjuk teknis Pendampingan kurikulum 2013 Sekolah menengah kejuruan

Eteokleous, Nikleia., dkk. (2012). Facebook a social networking tool for educational purposes: developing special interest groups. ICICTE Proceedings, 2012, 363-375

Guggenmos, K. \& McVety, P. J. (2010). Culinary essentials. California: McGrawHill Companies inc.
Kay, K.,\& Dardis, D. G. (2012). Framework for 21 st century learning. Diakses tanggal 20 Desember 2013, dari http://www. p21.org/about-us/p21-framework.

Leighbody, G. B., \& Kidd, D. M. (1968). Methods of teaching shop and technical subjects. New York: Delmar Publisher.

Mangkulo, H. S. (2010). Facebook for sekolahan. Jakarta: Elex Media Komputindo

Nazar, M. (2010). Pemanfaatan jejaring sosial sebagai sarana komunikasi sosial (KOMSOS) TNI AD. Jakarta: Subditbindiklat Dithubad.

Novriyanda. (2004). Seni ukir buah dan sayuran dalam rangkaian bunga dan dekorasi. Jakarta: Gramedia Pustaka Utama.

Nunung, \& Yauchti, D. (2011). Garnish cantik dan simpel dari sayur dan buah. Jakarta: Demedia Pustaka.

Smaldino, S. E., Lowther, D. L., \& Russell, J. D. (2008). Instructional technology and media for learning. New Jersey: Pearson Prentice Hall.

Soeprijanto. (2010). Pengukuran kinerja guru praktik kejuruan. Jakarta: CV. Tursina

Stanciau, A., Mihai, F., \& Aleca, O. (2012). Social networking as an alternative environment for education. Accounting and Management Information Systems, Vol. 11, No. 1, pp. 56-75. 